\title{
Sub-permafrost methane seepage from open-system pingos in Svalbard
}

\author{
Andrew J. Hodson ${ }^{1,2}$, Aga Nowak ${ }^{1}$, Mikkel T. Hornum ${ }^{1,3}$, Kim Senger ${ }^{1}$, Kelly Redeker $^{4}$, Hanne H. Christiansen ${ }^{1}$, \\ Søren Jessen $^{3}$, Peter Betlem ${ }^{1}$, Steve F. Thornton ${ }^{5}$, Alexandra V. Turchyn ${ }^{6}$, Snorre Olaussen ${ }^{1}$, and Alina Marca ${ }^{7}$ \\ ${ }^{1}$ Department of Arctic Geology, University Centre in Svalbard (UNIS), 9171 Longyearbyen, Norway \\ ${ }^{2}$ Department of Environmental Science, Western Norway University of Applied Sciences, Røyrgata 6, 6856 Sogndal, Norway \\ ${ }^{3}$ Department of Geosciences and Natural Resource Management, University of Copenhagen, 1350 Copenhagen K, \\ Copenhagen, Denmark \\ ${ }^{4}$ Department of Biology, University of York, York, YO10 5DD, UK \\ ${ }^{5}$ Department of Civil and Structural Engineering, University of Sheffield, Sheffield, S10 2TN, UK \\ ${ }^{6}$ Department of Earth Sciences, University of Cambridge, Cambridge, CB2 3EQ, UK \\ ${ }^{7}$ School of Environmental Sciences, University of East Anglia, Norwich, NR4 7TJ, UK
}

Correspondence: Andrew J. Hodson (andrewh@unis.no)

Received: 12 January 2020 - Discussion started: 3 February 2020

Revised: 17 September 2020 - Accepted: 24 September 2020 - Published: 9 November 2020

\begin{abstract}
Methane release from beneath lowland permafrost represents an important uncertainty in the Arctic greenhouse gas budget. Our current knowledge is arguably best developed in settings where permafrost is being inundated by rising sea level, which means much of the methane is oxidised in the water column before it reaches the atmosphere. Here we provide a different process perspective that is appropriate for Arctic fjord valleys where local deglaciation causes isostatic uplift to out pace rising sea level. We describe how the uplift induces permafrost aggradation in former marine sediments, whose pressurisation results in methane escape directly to the atmosphere via groundwater springs. In Adventdalen, central Spitsbergen, we show how the springs are historic features responsible for the formation of open-system pingos and capable of discharging brackish waters enriched with high concentrations of mostly biogenic methane (average $18 \mathrm{mgL}^{-1}$ ). Thermodynamic calculations show that the methane concentrations sometimes marginally exceed the solubility limit for methane in water at $0^{\circ} \mathrm{C}\left(41 \mathrm{mgL}^{-1}\right)$. Year-round emissions from the pingos are described. During winter, rapid methane loss to the atmosphere occurs following outburst events from beneath an ice blister. During summer, highly variable emissions occur due to complex surface processes at the seepage point and its inundation by surface runoff. In spite of this complexity, our observations confirm
\end{abstract}

that sub-permafrost methane migration deserves more attention for the improved forecasting of Arctic greenhouse gas emissions.

\section{Introduction}

Methane evasion to the atmosphere from thawing Arctic permafrost represents a significant risk to future greenhouse gas management, and so great emphasis has been placed upon quantifying the global importance of methane release from the active layer (see Dean et al., 2018). However, the potential for methane evasion from deeper sub-permafrost sources also exists (Anthony et al., 2012; Betlem et al., 2019; Kohnert et al., 2017), but, since the means by which the gas bypasses the permafrost are unclear, their possible timing, magnitude and impact are very uncertain. Recent research has provided significant insights into the role of landscape change and methane release from low-relief Arctic shelf environments typical of the Canadian, Siberian and north Alaskan coastlines (Kohnert et al., 2017; Frederick et al., 2016; Dmitrenko et al., 2011). Here, sea level inundation has enhanced methane escape by inducing permafrost thaw (Frederick et al., 2016). However, this mechanism is not relevant to many fjord coastlines in the Arctic because 
isostatic uplift has out paced sea level rise (Dutton et al., 2015). The uplift of sediments deposited in the fjord since the Last Glacial Maximum (LGM) has caused their exposure to the atmosphere, resulting in a period of freezing and permafrost aggradation (e.g. Cable et al., 2018; Gilbert et al., 2017, 2018). Fjord coastlines which have undergone significant isostatic uplift are typical of Svalbard (Norway), Novaya Zemlya (Russia), northern Greenland and the Canadian Arctic Archipelago. It is therefore significant that these areas are poorly represented in our current understanding of panArctic methane emissions from the land surface.

Fjords are notable for some of Earth's most rapid rates of sedimentation and organic carbon burial during glacial retreat, producing thick sediment sequences potentially conducive to biogenic methane production (Smith et al., 2015; Syvitski et al., 1986; Włodarska-Kowalczuk et al., 2019). In addition, the rocks underlying many Arctic fjords support either proven or highly probable natural gas resources (Gautier et al., 2009). Therefore, methane from geogenic sources such as coal beds and shale is also likely to be present. At the LGM, widespread methane hydrate stability zones were present under the ice sheets, providing a transient reservoir for both the biogenic and geogenic methane. The warmer period that caused the onset of ice sheet retreat after the LGM caused the gas hydrates to become thermodynamically unstable, and the methane began to escape rapidly through the recently uncovered sea floor (Crémière et al., 2016; Smith et al., 2001; Weitemeyer and Buffet, 2006). Evidence for such rapid fluid escape include pockmarks (Crémière et al., 2016; Portnov et al., 2016) (Fig. 1a) whose occurrence in Svalbard is particularly well-documented because some of them remain active today (Liira et al., 2019; Sahling et al., 2014). Sea floor methane emissions are subject to very significant removal processes due to dissolution and oxidation within the overlying water column (Mau et al., 2017). Further, Pohlman et al. (2017) have shown that sea floor gas emissions in coastal waters off Svalbard may also be offset by far greater rates of atmospheric $\mathrm{CO}_{2}$ sequestration into the overlying surface waters because the rising bubbles help nutrient-rich bottom waters rise up to fuel the photosynthesising plankton community. However, Hodson et al. (2019) showed that pockmarks exposed by isostatic uplift have the potential to form methane seepage pathways on land. Since any groundwater carrying the gas through the permafrost will be subject to freezing temperatures, these features are likely to become discernible as small, ice-cored hill forms known as open-system pingos (Fig. 1b). Therefore, pingos and other terrestrial seepages must be considered as migration pathways through what is otherwise regarded as an effective seal or "cryospheric cap" formed by the permafrost (Anthony et al., 2012). Such routes potentially represent the most harmful greenhouse gas emission pathway for methane trapped beneath permafrost because gas can escape directly to the atmosphere without removal by oxidation within the overlying water column of the fjord.
This paper therefore investigates how methane-rich fluids readily escape from beneath permafrost by exploiting the open-system pingos that have formed following isostatic uplift and permafrost aggradation in Svalbard's fjord landscape. We show that the pingos form natural "hot spots" for the ventilation of sub-permafrost methane directly to the atmosphere and use geochemical analyses to characterise the origins of both the groundwater and the methane that discharge from them.

\section{Methods}

\subsection{The field site}

Adventdalen's open-system pingos are located in a lowland valley that has been rapidly infilled by a pro-grading delta system throughout the Holocene. This was driven by ice sheet retreat commencing ca. 11000 years ago (Gilbert et al., 2018) and is represented by the landscape model in Fig. 1. As with many open-system pingos in central Spitsbergen, their formation was intricately linked to changes in groundwater dynamics that occur after such deltaic sediments emerge from below sea level and start to freeze. This permafrost aggradation increases hydraulic pressure and thus forces residual groundwater toward the land surface. Since the hydraulic conductivity of the fine-grained, uplifted marine sediments is very low (Hornum et al., 2020), the fluids are likely to exploit any former pockmarks that are uplifted with them (e.g. Hodson et al., 2019). Further freezing near the surface then results in expansion and the formation of a small hill with an ice core, or pingo, up to $40 \mathrm{~m}$ higher than the surrounding topography (Liestøl, 1996; Yoshikawa, 1993). Figure 2a shows that two pingos (Lagoon Pingo and Førstehytte Pingo) are situated in the lower part of the valley, whilst two others (Innerhytte Pingo and Riverbed Pingo) are up-valley and just beyond the former marine limit at ca. 70 m a.s.l. (above sea level). Lagoon Pingo, nearest to the coast, is thought to be less than 200 years old and has had springs documented from as early as 1926 (Liestøl, 1996; Yoshikawa and Nakamura, 1996). At Førstehytte Pingo, a spring has also been known to exist since the 1920s, but the pingo is thought to be much older. Radio-carbon dates for molluscs in the marine sediments uplifted by the Førstehytte Pingo give a maximum age limit of $7000 \pm 70$ years (Yoshikawa, 1993; Yoshikawa and Nakamura, 1996). Innerhytte Pingo and Riverbed Pingo are of an unknown age, and since they lack a cover of marine sediments containing mollusc shells, no radiocarbon dates are available.

Like many fjord valleys, the rate of sedimentation was extremely high during ice sheet retreat, and so a "wedge" of up to $60 \mathrm{~m}$ of valley infilling has occurred within the former marine limit (Cable et al., 2018; Gilbert et al., 2018). However, the permafrost in the valley floor of Adventdalen is up to $120 \mathrm{~m}$ thick, so much of the fine sediments have frozen 

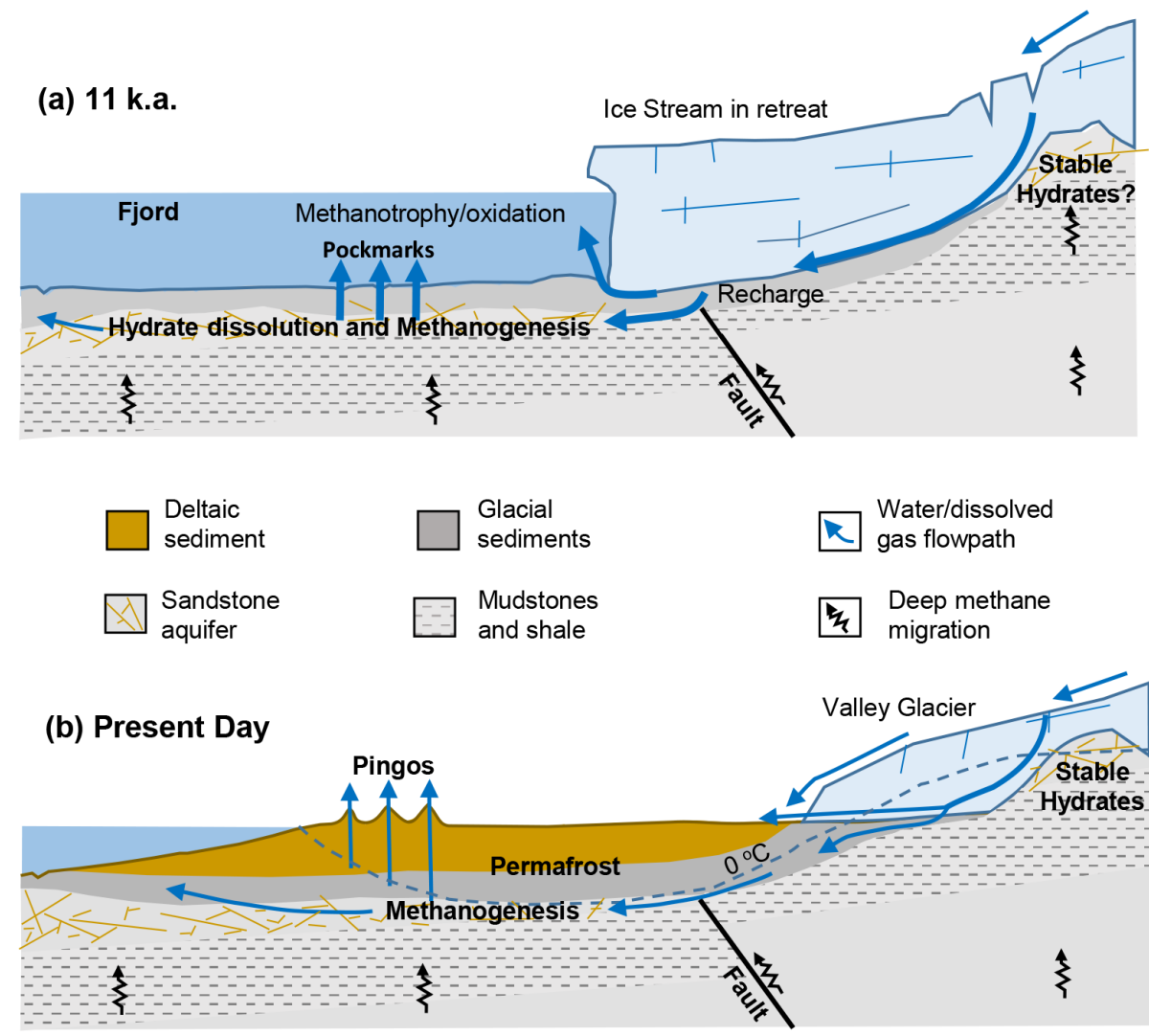

Figure 1. Landscape change and likely methane migration pathways in Adventdalen (thickness of geological units and sediments not to scale) (a) during deglaciation after the Last Glacial Maximum ca. 11000 years ago and (b) today following delta progradation, isostatic uplift and permafrost aggradation. The conceptual model of landscape change was based upon Gilbert et al. (2018).

since their exposure by isostatic uplift during the Holocene with the exception of the sediments closest to the contemporary shoreline and pockets of saline "cryopegs" further upvalley (Keating et al., 2018). There are no taliks beneath the river because river discharge volumes drop rapidly in late August which allows freezing to commence early in the winter. Although the typically fine-grained, frozen marine sediment infill in the valley has a low hydraulic conductivity, the underlying glacial tills, and in particular the upper (unfrozen) geological strata beneath that, seem to support important sub-permafrost fluid migration pathways (Huq et al., 2017; Hornum et al., 2020: Fig. 2b). Unique insights into the sub-permafrost geology were provided by the legacy of geological exploration in the region, which is currently managed by the Store Norske Spitsbergen Kulkompani (SNSK). This provided unpublished borehole records and geochemical data that allowed us to better understand the presence of methane and groundwater beneath the permafrost. Furthermore, geochemical and geophysical analysis of deep rock cores have also been undertaken in the valley as part of the University Centre in Svalbard (UNIS) $\mathrm{CO}_{2}$ Project (Braathen et al., 2012; Olaussen et al., 2019). Key sites for these earlier investigations are shown in Fig. 2a. Of par- ticular importance are the permeable, fractured sandstones of the Lower Cretaceous Helvetiafjellet Formation immediately beneath the permafrost westwards of Innerhytte Pingo and a ca. $400 \mathrm{~m}$ thick Lower Cretaceous to Middle Jurassic mudstone-dominated succession beneath that (the Rurikfjellet and Agardfjellet formations). The mudstone succession also outcrops eastwards from Innerhytte Pingo, as well as to the north at the base of the mountains (see cross section, Fig. 2b). Fractured, uplifted mudstone clasts therefore form the mantle lying over the Innerhytte and Riverbed pingos, whilst younger marine muds form the mantle over the Førstehytte and Lagoon pingos.

Earlier work has shown that the fractured sandstones host an important biogenic methane-rich aquifer, whilst the mudstones form an effective flow boundary that seems to suppress the upward migration of its own geogenic methane resource (Huq et al., 2017). The gas-rich upper sandstone aquifer therefore contains few hydrocarbons other than methane, whilst in the lower mudstone successions, ethane and propane have been detected at levels indicative of a geogenic gas source (Huq et al., 2017; Ohm et al., 2019). Fluid migration through the outcropping mudstones to the Innerhytte and Riverbed pingos is therefore likely to exploit faults 


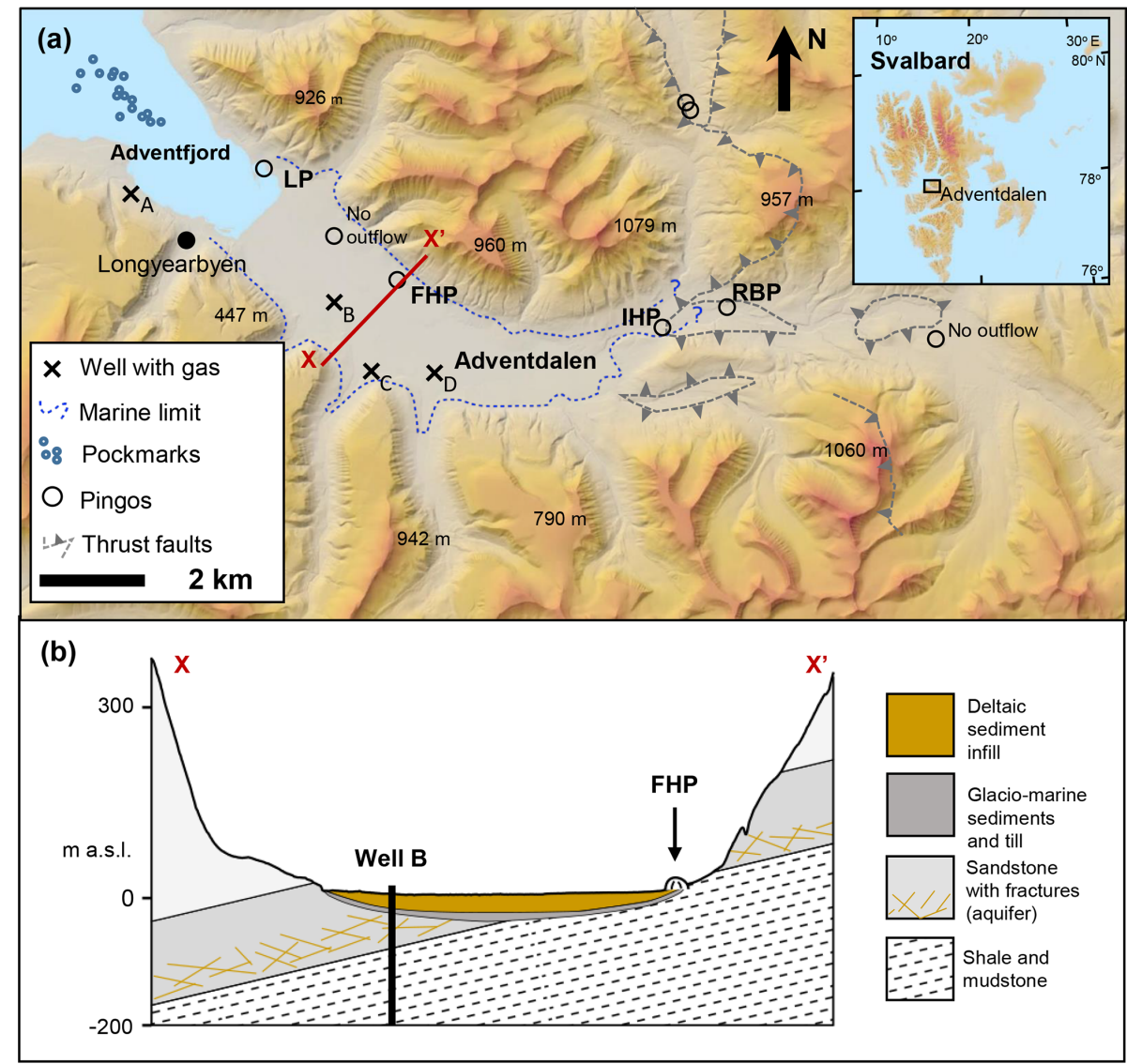

Figure 2. Adventdalen topography, pingos and geology. Active springs exist at Lagoon Pingo, Førstehytte Pingo, Innerhytte Pingo and Riverbed Pingo (LP, FHP, IHP and RBP, respectively). Well sites A and B are part of the University Centre in Svalbard (UNIS) $\mathrm{CO}_{2}$ Well Park (Braathen et al., 2012), whilst well sites C and D are part of the Store Norske Spitsbergen Kulkompani (SNSK) operations. Map developed online at http://www.svalbardkartet.npolar.no (last access: 1 August 2018).

(shown conceptually in Fig. 2b but very poorly understood), whilst fluid migration towards the Førstehytte and Lagoon pingos is likely to exploit the fractured sandstones of the Helvetiafjellet Formation and glacial tills immediately beneath the permafrost (Fig. 2b).

Four of six open-system pingos in Adventdalen discharged groundwater all year (Fig. 2a). In the summer, the springs were discernible as a discrete conduit discharging either into the base of a small pond (e.g. Lagoon Pingo), directly out of the pingo and down its flank (Førstehytte Pingo, Innerhytte Pingo), or straight out of the base of the pingo and into the Adventelva riverbed, which may or may not be flooded due to its braided nature (Riverbed Pingo). During summer, surface meltwater flooding in the valley hinders access to the pingos since the river must be crossed to gain access. At other times of the year, after freezing has commenced (usually late September until mid-May), spring water accumulates beneath a large ice blister. The pressure caused by continuous flow expands the ice blister, forcing its summit upwards by as much as $4 \mathrm{~m}$ by the end of winter. The expansion is periodically checked by turbulent outbursts of water that typically freeze within $100 \mathrm{~m}$ of the pingo. All four springs were sampled before the melt season after drilling up to $2 \mathrm{~m}$ through their winter ice cover, releasing pressurised flow.

\subsection{Fieldwork}

Field work involved consecutive springtime sampling campaigns (March-April) at the four pingos from 2015 until 2017. In addition, opportunistic sampling at the pingos was conducted in summer 2017 when low river levels made access to the field sites possible. We focused our sampling on the larger, discrete springs that were closest to the pingo summit, but in 2017, the spring that was sampled at Riverbed Pingo was in a different location to previous years (away from the foot of the pingo). This site is hereafter referred to as "Riverbed Pingo Distal", and it is differentiated for reasons that become apparent when our results are considered.

Pingo springs were sampled after drilling up to $3 \mathrm{~m}$ through their winter ice cover using a $7 \mathrm{~cm}$ diameter Kovacs drill and Stihl two-stroke engine. Although the icing surfaces were sometimes visibly cracked with an outflow 
of water, drilling was still employed to reduce the likelihood of oxygenation before sampling and contamination from local snow. At the sampling site, $\mathrm{pH}$, temperature, dissolved oxygen and oxidation-reduction potential (ORP) were recorded using Hach Lange HQ40D meters and dedicated electrodes/sensors. These were calibrated prior to use with the exception of the dissolved $\mathrm{O}_{2}$ measurement which was conducted using the luminescence method and thus used a factory-calibrated sensor tip. To prevent freezing problems and electrode malfunction, water samples were pumped through a custom-made, air-tight flow cell with an internal heating element maintaining the sample flow at ca. $7^{\circ} \mathrm{C}$.

\subsection{Analytical work}

Samples for dissolved iron and manganese analysis were syringe-filtered immediately in the field through $0.45 \mu \mathrm{m}$ filters into pre-cleaned $15 \mathrm{~mL}$ Eppendorf Tubes ${ }^{\circledR}$ before acidification to $\mathrm{pH} \sim 1.7$ using reagent grade $\mathrm{HNO}_{3}^{-}$(AnalaR $65 \%$ Normapur, VWR, IL, USA). The analysis of dissolved $\mathrm{Fe}$ and $\mathrm{Mn}$ was then completed using inductively coupled plasma mass spectrometry or ICP-MS (PerkinElmer ELAN DRC II, MA, USA). Precision errors of the analyses were less than $5 \%$ according to repeat analyses of mid-range standards with a detection limit of $1.0 \mu \mathrm{gL}^{-1}$. No contaminants were detected above this limit in the analyses of blank deionised water samples. Samples for major ion analysis (here $\mathrm{Ca}^{2+}, \mathrm{Mg}^{2+}, \mathrm{Na}^{+}, \mathrm{K}^{+}, \mathrm{Cl}^{-}, \mathrm{NO}_{3}^{-}, \mathrm{SO}_{4}^{2-}$ ) were also filtered in the same manner (but not acidified) and stored in $50 \mathrm{~mL}$ Corning centrifuge tubes after being triple rinsed with filtrate. The analysis was conducted on Dionex DX90 ion chromatographs with a detection limit of $0.02 \mathrm{mg} \mathrm{L}^{-1}$ for the lowest, undiluted analysis. Precision errors for these ions were all less than $5 \%$ for mid-range standards.

Charge balance calculations were used to provide the indicative values of $\mathrm{HCO}_{3}^{-}$and $\mathrm{CO}_{3}^{2-}$, given (as DIC or dissolved inorganic carbon) in Table 1. Excess $\mathrm{CO}_{2}$ levels were estimated from calculations of the partial pressure of $\mathrm{CO}_{2}$ using the online WEB-PHREEQ geochemical speciation software (https://www.ndsu.edu/webphreeq/, last access: 15 January 2018).

Samples for the determination of dissolved methane and carbon dioxide concentrations, as well as $\delta^{13} \mathrm{C}_{-}-\mathrm{CH}_{4}$ and $\delta^{13} \mathrm{C}$-DIC, of the waters were taken directly from the spring following the immersion, complete filling and sealing of a $22 \mathrm{~mL}$ Wheaton bottle with a crimp top lid with septum. The samples were stored inverted under water at $4{ }^{\circ} \mathrm{C}$ until analysis. The analysis of the $\mathrm{CH}_{4}$ was performed by gas chromatography on a Shimadzu GC-2014 instrument equipped with a methanizer and flame ionisation detector using a $30 \mathrm{~m}$ GS-Q $0.53 \mathrm{~mm}$ internal diameter column with $\mathrm{N}_{2}$ as a carrier gas at a flow rate of $8 \mathrm{~mL} \mathrm{~min}^{-1}$. The sample size was $100 \mu \mathrm{L}$, and the sample run time was $3 \mathrm{~min}$ at $40^{\circ} \mathrm{C}$. Concentrations of dissolved $\mathrm{CH}_{4}$ were obtained according to a mass balance calculation for the samples (McAuliffe, 1971), in which a known volume of $\mathrm{N}_{2}$ was injected into sample vials to create a headspace whilst allowing sample displacement through an outlet needle to prevent pressurisation (Tyler et al., 1997). After shaking and equilibration (2 h), the $\mathrm{CH}_{4}$ partitioned into the headspace was analysed by gas chromatography and flame ionisation detection (GC-FID), and the corresponding mass in the gas and aqueous phase was determined by Henry's law to obtain a final concentration in the water sample. Six calibration gas standards were prepared on the day of analysis by serial dilution of certificated $60 \% \mathrm{CH}_{4}: 40 \% \mathrm{CO}_{2}$ mixed gas using $\mathrm{O}_{2}$-free $\mathrm{N}_{2}$ as the balance gas. The calibration was linear across the range 0-140000 ppmv, and the detection limit was equivalent to $\sim 0.017 \mathrm{mg} \mathrm{L}^{-1}$. Repeat analyses of mid-range standards indicated a precision error of less than $1.3 \%$.

Analysis of dissolved methane isotopic composition and concentration was performed using the gas headspace equilibration technique (Magen et al., 2014) (5 mL sampled water was injected into a Viton-stoppered, He-flushed $120 \mathrm{~mL}$ glass serum vial). A total of $10 \mathrm{~mL}$ of the headspace was then flushed through a $2 \mathrm{~mL}$ sample loop and injected onto a $25 \mathrm{~m}$ molecular sieve column within an Agilent 7890B gas chromatograph attached to an Isoprime100 isotope ratio mass spectrometer (IRMS) (Tyler et al., 1997). Analytical precision errors for samples greater than $3 \mathrm{ng} \mathrm{C}$ were better than $0.3 \%$ or for isotopic values and less than $3.5 \%$ for concentration based on methane standard injections. $\delta^{13} \mathrm{C}_{\text {DIC }}$ was measured by a continuous flow isotopic ratio mass spectrometer (Thermo-Finnigan Delta V with GasBench interface) and an error of $0.1 \%$ o. All $\delta^{13} \mathrm{C}_{\mathrm{DIC}}$ and $\delta^{13} \mathrm{C}_{\mathrm{CH}_{4}}$ values are reported compared to the Vienna Pee Dee Belemnite (VPDB) standard.

Samples for water isotope analysis were collected as unfiltered $20 \mathrm{~mL}$ aliquots in a screw-top high density polyethylene bottle. The bottles were subsampled into $1.5 \mathrm{~mL}$ vials with septa closures and loaded into the auto-sampler tray of a cavity ring-down spectroscopy (CRDS) instrument (Picarro V 1102-i model). Each sample was injected and measured six times using $2.5 \mu \mathrm{L}$ of water for each injection. Together with the samples, two secondary international standards (USGS 64444 and USGS 67400) and one internal laboratory standard (NTW, Norwich tap water) were measured; each was injected 10 times in order to minimise memory effects. Final isotopic compositions were calculated using the calibration line based on the secondary international standards and reported in per mille (\%o) units with respect to the Vienna Standard Mean Ocean Water (VSMOW) on the VSMOWSLAP scale. The precision error of the measurements was $0.1 \%$ for $\delta^{18} \mathrm{O}$ and $0.3 \%$ for $\delta \mathrm{D}$. 
Table 1. Geochemical characteristics of Adventdalen pingo springs during pre-melt season sampling. All units are in milligrams per litre $\left(\mathrm{mgL}^{-1}\right)$ unless otherwise stated. $\mathrm{NO}_{3}$ is reported as milligrams of nitrogen per litre $\left(\mathrm{mg} \mathrm{NL}^{-1}\right)$, and "b.d." means below detection (ca. $\left.0.02 \mathrm{mg} \mathrm{L}^{-1}\right)$.

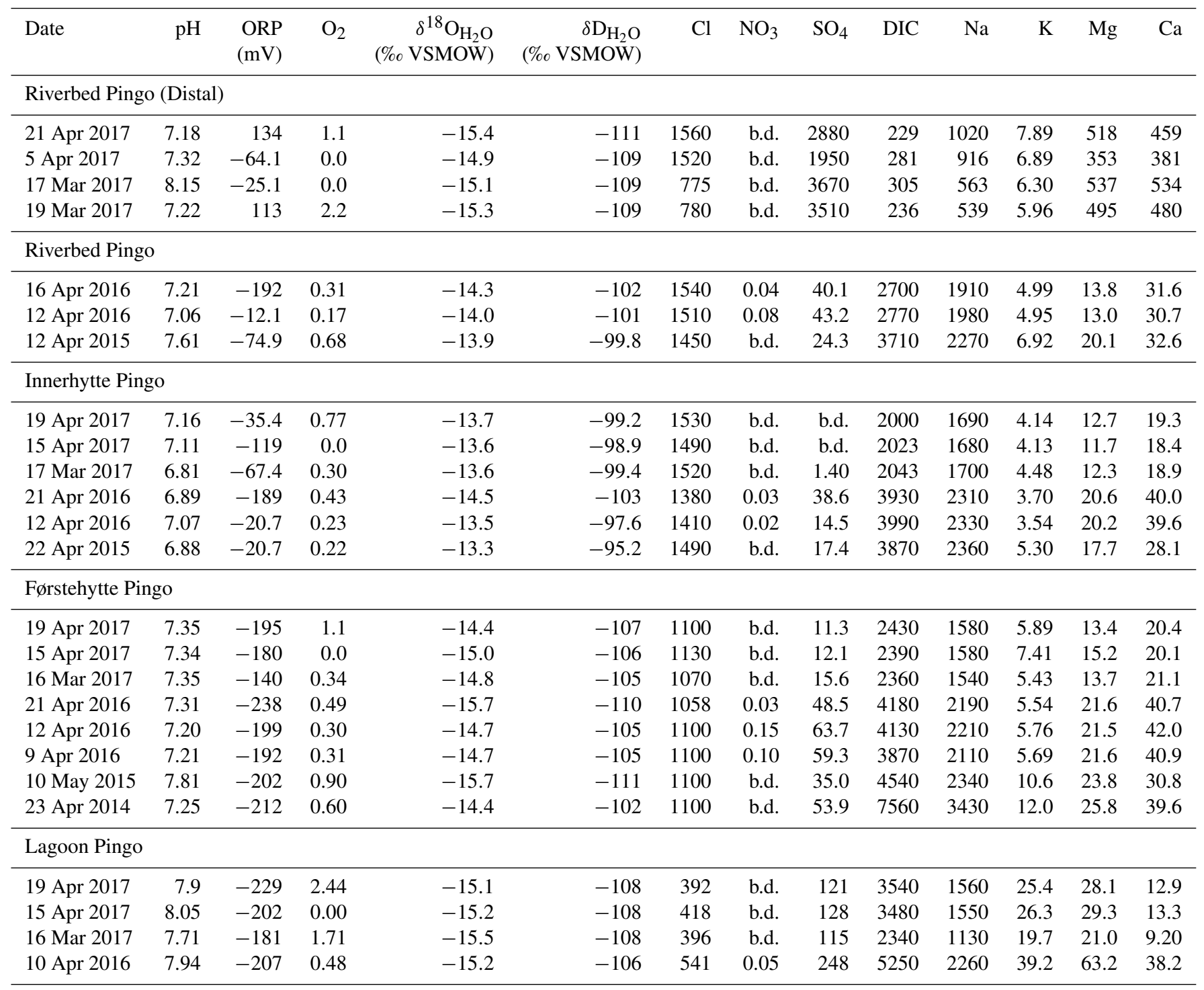

\section{Results}

\subsection{Sub-permafrost groundwater chemistry inferred from pingo springs}

Table 1 shows the geochemistry of all the water samples collected prior to the onset of snow melt from the open-system pingos in Adventdalen. These waters were typically brackish $\left(\mathrm{Cl}^{-}\right.$concentrations $\left.390-1600 \mathrm{mg} \mathrm{L}^{-1}\right)$, largely lacking in dissolved oxygen $\left(0.00-2 \mathrm{mg} \mathrm{L}^{-1}\right)$ and $\mathrm{NO}_{3}^{-}(\leq$ $\left.0.15 \mathrm{mg} \mathrm{L}^{-1}\right)$, and with a $\mathrm{pH}$ from circum-neutral to alkaline (pH 6.8-8.2). Figure 3a shows oxidation-reduction potential (ORP) measurements indicating that strongly reducing conditions (negative ORP) existed nearest to the coast (typically less than $-180 \mathrm{mV}$ at the Førstehytte and Lagoon pingos), whilst higher, more variable values were encountered upvalley $(-189$ to $+130 \mathrm{mV})$ at the Innerhytte and Riverbed pingos.

With the exception of the Riverbed Pingo Distal samples from 2017, the generally observed water type was $\mathrm{Na}$ $\mathrm{HCO}_{3}$ with a saturation index (SI) for calcite indicating near-equilibrium $\left(\mathrm{SI}_{\text {calcite }}=0.1 \pm 0.4\right)$ according to WEBPHREEQ. The dominance of $\mathrm{Na}^{+}$over the other cations $\left(\mathrm{Ca}^{2+}, \mathrm{Mg}^{2+}\right.$ and $\mathrm{K}^{+}$; Table 1) and the increasing $\mathrm{Na}^{+}$to $\mathrm{Cl}^{-}$ratios towards the coast (Fig. 3a) show how cation exchange (freshening) and rock-weathering effects were increasingly influential down the valley. Concentrations of $\mathrm{SO}_{4}^{2-}$ in most samples were far lower than expected when 
(a)

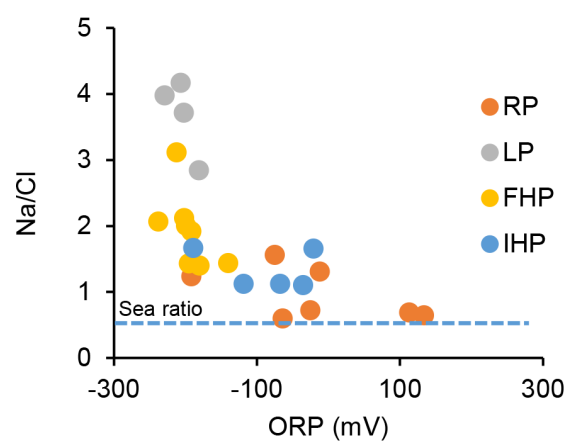

(c)

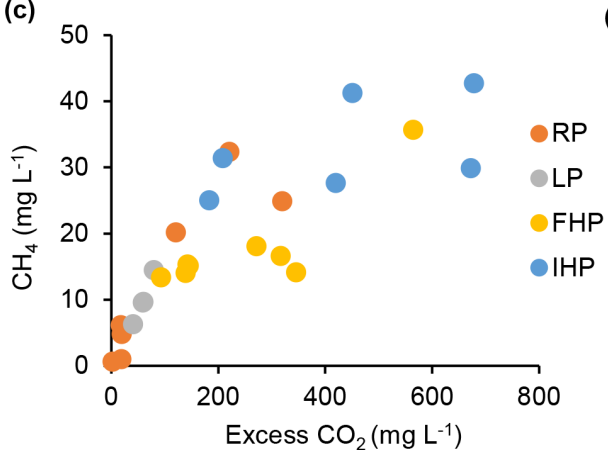

(b)

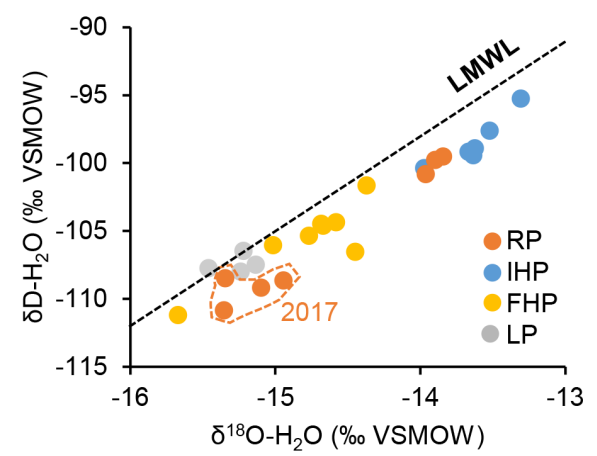

(d)

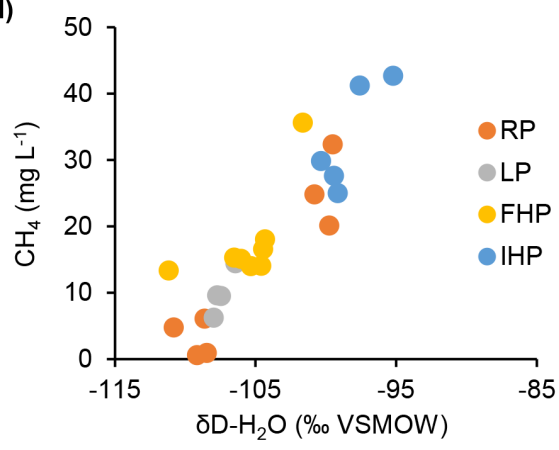

Figure 3. Key geochemical and dissolved gas characteristics in spring waters draining Riverbed Pingo (RP), Innerhytte Pingo (IHP), Førstehytte Pingo (FHP) and Lagoon Pingo (LP). "LMWL" denotes the local meteoric water line. The legend in (a) applies also to (b)-(d).

compared to late summer baseflow concentrations in local rivers (e.g. Hodson et al., 2016; Rutter et al., 2011; Yde et al., 2008). However, the Riverbed Pingo Distal samples revealed a distinctly different spring water chemistry with a $\mathrm{Mg}-\mathrm{Ca}-$ $\mathrm{SO}_{4}$ water type, far higher $\mathrm{SO}_{4}^{2-}$ concentrations and a saturation index for gypsum that reached equilibrium $\left(\mathrm{SI}_{\text {gypsum }}=\right.$ $0.0 \pm 0.1)$ according to WEB-PHREEQ. Otherwise, the Riverbed Pingo samples from 2015 and 2016 showed subsaturation with respect to gypsum $\left(\mathrm{SI}_{\text {gypsum }}=-2.9 \pm 0.5\right)$. The markedly different $\mathrm{Mg}-\mathrm{Ca}-\mathrm{SO}_{4}$ water type therefore suggests a different groundwater source whose composition was governed by gypsum-driven de-dolomitisation, a process wherein very reactive gypsum catalyses the replacement of dolomite by calcite (Bischoff et al., 1994). This is further supported by the different $\delta^{18} \mathrm{O}-\mathrm{H}_{2} \mathrm{O}$ and $\delta \mathrm{D}-\mathrm{H}_{2} \mathrm{O}$ stable isotope characteristics of the Riverbed Pingo Distal waters, which Fig. 3b suggests were more similar to those encountered at Lagoon Pingo.

With the exception of the Riverbed Pingo Distal waters, Fig. 3b indicates a general westward depletion (decrease) in both water isotopes towards the coast where water samples also lie closest to the local meteoric water line (LMWL) (Rozanski et al., 1993). Although Fig. 4b shows that none of the waters depart significantly from the LMWL, a linear regression model produces a lower slope (6.09) than that which is associated with the LMWL (i.e. 6.97), suggesting minor isotopic fractionation associated with partial re-freezing (Lacelle, 2011).

\subsection{Methane geochemistry in the pingo springs}

Table 2 shows that concentrations of methane in pingo spring waters in both the pre-melt season and the summer periods lay in the range of $0.6-42.6 \mathrm{mg} \mathrm{L}^{-1}$, which is up to 5 orders of magnitude greater than calculated atmospheric thermodynamic equilibrium values and places the most concentrated values marginally above the solubility limit for fresh water at $0{ }^{\circ} \mathrm{C}$ (i.e. $41 \mathrm{mg} \mathrm{L}^{-1}$ ). The data include samples collected opportunistically from the springs during the summer melt season. The dissolved carbon dioxide concentrations were also in excess of atmospheric equilibrium by as much as $700 \mathrm{mg} \mathrm{L}^{-1}$ at Innerhytte Pingo. Temporal variability in the dissolved gas concentrations was significant at all sites but greatest at Riverbed Pingo Distal, where there were generally much lower methane and excess $\mathrm{CO}_{2}$ concentrations. The methane concentration (at all sites) was positively correlated $(p<0.05)$ with excess $\mathrm{CO}_{2}(r=0.86$; Fig. $3 \mathrm{c})$, the stable isotopes of water $\left(\delta^{18} \mathrm{O}-\mathrm{H}_{2} \mathrm{O}, r=0.86\right.$ and $\delta \mathrm{D}-\mathrm{H}_{2} \mathrm{O}$, $r=0.91$ : Fig. $4 \mathrm{~d})$ and $\mathrm{Na}^{+}(r=0.74)$.

Table 2 shows that the $\delta^{13} \mathrm{C}$ of methane and dissolved inorganic carbon ( $\delta^{13} \mathrm{C}-\mathrm{CH}_{4}$ and $\delta^{13} \mathrm{C}$-DIC, respectively) were variable, especially at Lagoon Pingo and Førstehytte Pingo. The $\delta^{13} \mathrm{C}-\mathrm{CH}_{4}$ lay between $-70.7 \%$ and $-48.2 \%$ VPDB 
Table 2. The $\delta^{13} \mathrm{C}$ composition and concentration of methane and dissolved inorganic carbon (DIC) in pingo springs. The excess of $\mathrm{CO}_{2}$ relative to equilibrium with the atmosphere is " $\mathrm{eCO}_{2}$ ". Samples collected opportunistically during the summer are in bold, "n.d." means "not determined, and "b.d." means results were below the detection limit.

\begin{tabular}{|c|c|c|c|c|}
\hline Date & $\mathrm{CH}_{4}\left(\mathrm{mg} \mathrm{L}^{-1}\right)$ & $\mathrm{eCO}_{2}\left(\mathrm{mg} \mathrm{L}^{-1}\right)$ & $\delta^{13} \mathrm{C}-\mathrm{CH}_{4}(\% \circ \mathrm{VPDB})$ & $\delta^{13} \mathrm{C}-\mathrm{DIC}(\% \circ \mathrm{VPDB})$ \\
\hline \multicolumn{5}{|c|}{ Riverbed Pingo (Distal) } \\
\hline 21 Apr 2017 & 4.78 & 19.6 & -54.4 & 12.6 \\
\hline 5 Apr 2017 & 6.23 & 17.3 & -55.0 & 12.5 \\
\hline 17 Mar 2017 & 0.61 & 2.36 & b.d. & 10.1 \\
\hline 19 Mar 2017 & 0.97 & 18.9 & b.d. & 10.1 \\
\hline \multicolumn{5}{|c|}{ Riverbed Pingo } \\
\hline 16 Apr 2016 & 32.4 & 221 & -55.6 & n.d. \\
\hline 12 Apr 2016 & 24.9 & 320 & -51.5 & n.d. \\
\hline 12 Apr 2015 & 20.2 & 121 & -55.9 & n.d. \\
\hline \multicolumn{5}{|c|}{ Innerhytte Pingo } \\
\hline 23 Sep 2017 & 25.0 & 183 & -53.8 & 27.1 \\
\hline 19 Apr 2017 & 31.4 & 208 & -55.9 & 26.7 \\
\hline 15 Apr 2017 & 27.6 & 420 & -56.1 & 12.6 \\
\hline 17 Mar 2017 & 30.0 & 672 & -55.7 & 26.3 \\
\hline 21 Apr 2016 & 41.3 & 451 & -57.8 & n.d. \\
\hline 12 Apr 2016 & 42.6 & 678 & -51.8 & n.d. \\
\hline 22 Apr 2015 & 25.0 & 183 & -49.7 & n.d. \\
\hline \multicolumn{5}{|c|}{ Førstehytte Pingo } \\
\hline 3 Oct 2017 & 11.9 & 641 & -64.2 & 2.5 \\
\hline 13 Sep 2017 & 16.5 & 770 & -64.7 & 2.7 \\
\hline 19 Apr 2017 & 15.3 & 143 & -48.2 & 1.7 \\
\hline 15 Apr 2017 & 15.1 & 145 & -52.3 & 2.4 \\
\hline 16 Mar 2017 & 14.0 & 139 & -54.0 & 2.4 \\
\hline 21 Apr 2016 & 18.1 & 271 & -67.4 & n.d. \\
\hline 12 Apr 2016 & 14.1 & 346 & -55.3 & n.d. \\
\hline 9 Apr 2016 & 16.6 & 317 & -56.1 & n.d. \\
\hline 10 May 2015 & 13.4 & 93.0 & -67.1 & n.d. \\
\hline \multicolumn{5}{|l|}{ Lagoon Pingo } \\
\hline 28 Sep 2017 & 7.26 & 210 & -70.7 & -8.4 \\
\hline 24 Aug 2017 & 9.50 & 58.7 & -69.8 & n.d. \\
\hline 19 Apr 2017 & 6.30 & 40.7 & -55.6 & n.d. \\
\hline 15 Apr 2017 & 9.63 & 60.1 & -48.3 & n.d. \\
\hline 16 Mar 2017 & 13.7 & 79.6 & -62.0 & n.d. \\
\hline 10 Apr 2016 & 9.50 & 58.7 & -66.8 & n.d. \\
\hline
\end{tabular}

which is indicative of biogenic methane at the ${ }^{13} \mathrm{C}$-depleted (more negative) end of the scale and either partially oxidised biogenic or geogenic methane at the ${ }^{13} \mathrm{C}$-enriched (more positive) upper end (Schoell, 1980). Table 2 also includes samples collected opportunistically from the springs during the summer. These show that the methane concentration in summer is within the range reported during late winter. The $\delta^{13} \mathrm{C}^{-} \mathrm{CH}_{4}$ and $\delta^{13} \mathrm{C}$-DIC values of the summer samples are also similar to the late winter, although the $\delta^{13} \mathrm{C}_{-} \mathrm{CH}_{4}$ is marginally lower $\left({ }^{13} \mathrm{C}\right.$-depleted) at Lagoon Pingo, and the summer $\delta^{13} \mathrm{C}$-DIC values at Førstehytte Pingo and Innerhytte
Pingo are slightly higher $\left({ }^{13} \mathrm{C}\right.$-enriched) than typical values in late winter.

Figure 4 shows that all measured $\delta^{13} \mathrm{C}_{-} \mathrm{CH}_{4}$ values in the pingo springs compare well with the results of the pore gas extractions (range $-53 \%$ VPDB to $-69 \%$ VPDB) from the upper core sections at the $\mathrm{CO}_{2}$ Well Park (Well Site B in Fig. 2a; data from Huq et al., 2017). Here, the methane in the permafrost and underlying host rocks of the subpermafrost aquifer has been attributed to a biogenic source because the $\delta^{13} \mathrm{C}_{-} \mathrm{CH}_{4}$ values are moderately ${ }^{13} \mathrm{C}$-depleted (i.e. more negative) and the concentrations of other hydrocar- 


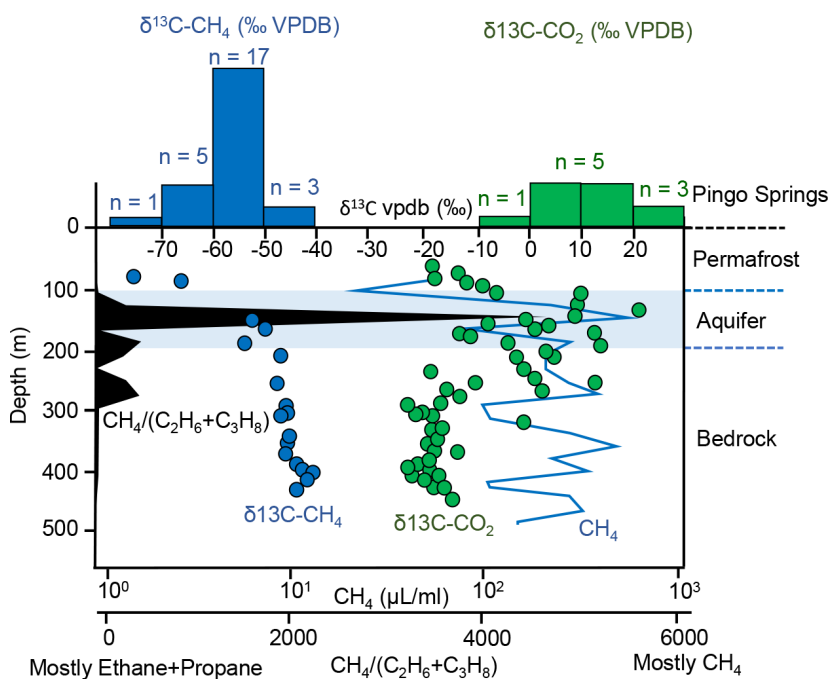

Figure 4. Histograms showing the stable isotope composition of methane and $\mathrm{CO}_{2}$ in pingo spring waters (from Table 2) for comparison with published pore gases from different depths at the $\mathrm{CO}_{2}$ Well Park (Well Site B in Fig. 2). The ratio of methane to the sum of ethane and propane (all in $\mu \mathrm{LmL}^{-1}$ ) is shown to indicate where biogenic methane is most likely (i.e. high values). Also shown are the approximate lower boundary of the permafrost and the aquifer beneath it.

bons (propane and ethane) are low relative to methane (see Fig. 4). Nearby, methane with $\delta^{13} \mathrm{C}_{-} \mathrm{CH}_{4}$ between $-48.9 \%$ o and $-52.9 \%$ VPDB and no other detectable hydrocarbons was also found immediately beneath the permafrost at well sites $\mathrm{C}$ and $\mathrm{D}$ in association with a Cl-rich $\left(1500 \mathrm{mg} \mathrm{L}^{-1}\right)$ groundwater (Store Norske Spitsbergen Kulkompani, unpublished report SN1983-004). In this case, both the $\delta^{13} \mathrm{C}_{-} \mathrm{CH}_{4}$ and the $\mathrm{Cl}^{-}$concentrations compare favourably to the values at the Innerhytte and Riverbed pingos. By contrast, the

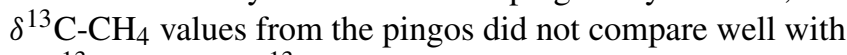
the ${ }^{13} \mathrm{C}$-enriched $\delta^{13} \mathrm{C}^{-\mathrm{CH}_{4}}$ values (range $-50 \%$ o to $-32 \%$ o VPDB) recorded from the deeper shale unit (i.e. $>300 \mathrm{~m}$; see Fig. 4) at Well Site B by Huq et al. (2017). These values were assumed to indicate the deeper geogenic methane source because ethane and propane were also detected at significant concentrations relative to the methane (see also Ohm et al., 2019).

Figure 4 also shows that the $\delta^{13} \mathrm{C}$-DIC values (range $-8.5 \%$ o to $+26 \%$ VPDB) observed in the pingo springs do not compare well with the values from the lower shalerich units of the rock cores either (range $-26 \%$ o to $+21 \%$ o VPDB; Huq et al., 2017). This difference cannot be attributed to differences in the DIC speciation among our water samples (containing $\mathrm{CO}_{2(\mathrm{aq})}, \mathrm{H}_{2} \mathrm{CO}_{3}, \mathrm{HCO}_{3}^{-}$and $\mathrm{CO}_{3}^{2-}$ ) and the published rock pore gas samples $\left(\mathrm{CO}_{2(\mathrm{~g})}\right.$ only). The low $\delta^{13} \mathrm{C}$ DIC that is missing from the pingo water samples is derived from organic matter respiration and is known to be present in local riverine runoff $\left(\delta^{13} \mathrm{C}\right.$-DIC range $-15 \%$ o to $-4 \%$ o
VPDB; Hindshaw et al., 2016). Therefore, the higher $\delta^{13} \mathrm{C}$ DIC signatures of the pingo springs are most similar to those seen in the upper aquifer zone of the cores.

\section{Discussion}

\subsection{Groundwater geochemical environment and methane concentrations}

The geochemistry of the pingo springs is significantly different to surface waters in the Adventdalen watershed (see Hodson et al., 2016; Rutter et al., 2011; Yde et al., 2008). Their high $\mathrm{Cl}^{-}$concentrations and distinct $\mathrm{Na}-\mathrm{HCO}_{3}$ freshening signature indicate the incorporation of brackish-marine water from either the uplifted Holocene marine sediments, the fjord or a mixture of the two. Importantly, the removal of nitrate and sulfate and the presence of biogenic methane indicate that microbially mediated processes are operating (denitrification, sulfate reduction and methanogenesis, respectively). These decrease the redox potential of the groundwater towards the low ORP conditions found at the coast (Fig. 3a). The strikingly different water chemistry dominated by $\mathrm{Mg}-\mathrm{Ca}-\mathrm{SO}_{4}$ in the Riverbed Pingo Distal samples during 2017 seems to indicate an additional groundwater type that is strongly influenced by the gypsum- and dolomitebearing rocks that outcrop east of Adventdalen or lie at considerable depth (beneath the Agardfjellet Formation) within the study area in Fig. 2. Due to the low hydraulic conductivity of the shale units of the Rurikfjellet and Agardfjellet formations, their influence upon springs at the Riverbed Pingo Distal site is presumably made possible by groundwater migration along the faults in the vicinity of the pingo (Fig. 2a). Otherwise, sub-permafrost groundwater migration in the study area seems dominated by the exploitation of the sub-permafrost aquifer hosted by the Helvetiafjellet Formation in the lower valley (see Hornum et al., 2020).

The strongest predictors of the methane content in the pingo springs are $\delta^{18} \mathrm{O}-\mathrm{H}_{2} \mathrm{O}$ and $\delta \mathrm{D}-\mathrm{H}_{2} \mathrm{O}$ (Fig. 3d). Since the $\delta^{18} \mathrm{O}-\mathrm{H}_{2} \mathrm{O}$ and $\delta \mathrm{D}-\mathrm{H}_{2} \mathrm{O}$ values show only a minor departure from the LMWL (Fig. 3b), this indicates a strong water source control upon the gas concentration emerging from the pingos. Methane concentrations generally increase up-valley where $\delta^{18} \mathrm{O}-\mathrm{H}_{2} \mathrm{O}$ and $\delta \mathrm{D}-\mathrm{H}_{2} \mathrm{O}$ become more ${ }^{18} \mathrm{O}$ enriched. Since sea water is $\delta^{18} \mathrm{O}$ - and $\delta \mathrm{D}$-enriched relative to freshwater, the simplest, although initially counterintuitive, explanation for this change is an inland increase in the mixing ratio of marine water within the sub-permafrost groundwater. A statistically significant $(p<0.05)$ relationship between $\mathrm{Cl}^{-}$and methane $(r=0.74)$ also becomes apparent when the Riverbed Pingo Distal samples are excluded. The dependence of the methane concentration upon $\mathrm{Cl}^{-}$, $\delta^{18} \mathrm{O}-\mathrm{H}_{2} \mathrm{O}$ and $\delta \mathrm{D}-\mathrm{H}_{2} \mathrm{O}$ is therefore consistent with deeper, denser sub-permafrost brines providing the water source to the pingo springs further inland. Hornum et al. (2020) show 
how this most likely reflects a general increase in the thickness of the permafrost with distance from the coast (shown crudely in Fig. 1b). The presence of the $\mathrm{Mg}-\mathrm{Ca}-\mathrm{SO}_{4}$ groundwater in the Riverbed Pingo Distal samples is also consistent with this interpretation because the gypsum-hosting Permian strata lie beneath the Agardfjellet Formation. Further downvalley where permafrost is thinner, a greater mixing ratio of fresher, low-density groundwater discharges from the pingo springs. Its more depleted (lower) $\delta^{18} \mathrm{O}-\mathrm{H}_{2} \mathrm{O}$ and $\delta \mathrm{D}-\mathrm{H}_{2} \mathrm{O}$ signature is consistent with dilution by snow and ice melt from the mountains that flank the main valley axis near the coast (Yde et al., 2008).

\subsection{Methane sources and removal}

A comparison of the pingo $\delta^{13} \mathrm{C}_{-} \mathrm{CH}_{4}$ to the rock core gas samples in Fig. 4 shows that mixtures of biogenic methane (lower $\delta^{13} \mathrm{C}-\mathrm{CH}_{4}$ signatures) and geogenic methane (higher $\delta^{13} \mathrm{C}_{-} \mathrm{CH}_{4}$ signatures) might be present beneath the permafrost. However, evidence for a significant geogenic methane contribution to the pingo springs is equivocal and seems unlikely given the low rates of fluid migration that may be expected in the deeper shale-rich Rurikfjellet and Agardfjellet formations. Therefore, the partial oxidation of biogenic methane most likely explains the occasionally higher $\delta^{13} \mathrm{C}_{-} \mathrm{CH}_{4}$ signatures in the pingo springs due to the preferential oxidation of the ${ }^{12} \mathrm{C}$ isotopes (leaving the residual pool ${ }^{13} \mathrm{C}$ enriched; Schoell, 1980). The most variable $\delta^{13} \mathrm{C}-\mathrm{CH}_{4}$ values were encountered at the Førstehytte and Lagoon pingos (mean \pm 1 standard deviation; $-58.8 \pm 7.11 \%$ V VPDB and $-62.2 \pm 8.81 \%$ VPDB, respectively) and include the only low $\delta^{13} \mathrm{C}-\mathrm{CH}_{4}$ values, which can be attributed to biogenic methane with reasonable certainty (Table 2). Significant variations in these $\delta^{13} \mathrm{C}$ $\mathrm{CH}_{4}$ values sometimes occurred relatively rapidly, for example, from $-55.3 \%$ o to $-67.4 \%$ VPDB in just $9 \mathrm{~d}$ at Førstehytte Pingo (April 2016) or from $-62.0 \%$ o to $-48.3 \%$ o to $-55.6 \%$ VPDB over $34 \mathrm{~d}$ at Lagoon Pingo (March to April 2017). Rather than invoking an unlikely rapid switching between geogenic $\left({ }^{13} \mathrm{C}_{-} \mathrm{CH}_{4}\right.$-enriched $)$ and biogenic $\left(\delta^{13} \mathrm{C}_{-} \mathrm{CH}_{4}\right.$-depleted) methane sources, it is far more plausible that this variability was caused by changing degrees of oxidation of biogenic methane during storage beneath the surface ice blisters at the pingos. We therefore contend that as storage beneath an ice lid proceeds, the $\delta^{13} \mathrm{C}^{-\mathrm{CH}_{4}}$ at these sites will become increasingly $\delta^{13} \mathrm{C}-\mathrm{CH}_{4}$-enriched until hydraulic or thermal fracturing allows the trapped fluids to escape. Methanotrophic microbial communities in the marine muds represent a plausible mechanism for the enrichment (Hodson et al., 2019). After an outburst event, refreezing then seals the system, and the void fills once more with $\delta^{13} \mathrm{C}_{-} \mathrm{CH}_{4}$ depleted biogenic methane. As a consequence, the time that elapsed since the last fracture event, as well as the volume fraction of the fluids that managed to escape before refreezing, is likely to cause the notable variations in the $\delta^{13} \mathrm{C}_{-}-\mathrm{CH}_{4}$ of our samples. For this reason, Table 2 shows that samples collected opportunistically at these sites during late summer (when no ice lid existed) consistently showed the depleted $\delta^{13} \mathrm{C}-\mathrm{CH}_{4}$ values (i.e. between $-60 \%$ and $-70 \%$ VPDB) expected of a biogenic source.

The high methane concentrations at Innerhytte Pingo, sometimes observed near the solubility limit (ca. $41 \mathrm{mg} \mathrm{L}^{-1}$ ), were characterised by limited variability in $\delta^{13} \mathrm{C}_{-} \mathrm{CH}_{4}$ (mean $-54.4 \pm 2.82 \%$ 。PDB). The $\delta^{13} \mathrm{C}_{-} \mathrm{CH}_{4}$ values at nearby Riverbed Pingo ( $-54.5 \pm 1.76 \%$ VPDB) were almost identical and again showed far less variability than at the Førstehytte and Lagoon pingos. If the high concentrations and invariable $\delta^{13} \mathrm{C}_{-} \mathrm{CH}_{4}$ are indicative of minimal removal or carbon isotope fractionation beneath an ice lid, then these results reveal a different (more ${ }^{13} \mathrm{C}$-enriched) $\delta^{13} \mathrm{C}-\mathrm{CH}_{4}$ source signature than at Lagoon Pingo and Førstehytte Pingo. A mixture of geogenic and biogenic gas therefore seems more plausible here not least because the $\delta^{13} \mathrm{C}_{-} \mathrm{CH}_{4}$ signatures lie close to the geogenic methane $\delta^{13} \mathrm{C}-\mathrm{CH}_{4}$ signature inferred from the lower shale units by Huq et al. (2017) (i.e. $\delta^{13} \mathrm{C}$ $\mathrm{CH}_{4}$ ca. $-45 \%$ VPDB and above; Fig. 4). However, the ${ }^{13} \mathrm{C}_{-} \mathrm{CH}_{4}$ signatures are in fact closest to the gas discovered in the Helvetiafjellet aquifer just below the permafrost at wells $\mathrm{C}$ and $\mathrm{D}$ (i.e. $\delta^{13} \mathrm{C}_{-} \mathrm{CH}_{4}$ between $-48.9 \%$ and $-52.9 \%$ VPDB), which is known to be almost entirely biogenic because there are low or undetectable levels of other hydrocarbons (ethane and propane) according to both SNSK reports and Huq et al. (2017). Furthermore, the high $\delta^{13} \mathrm{C}$ DIC (>10\%) at both the Innerhytte and Riverbed pingos, also observed in the sub-permafrost aquifer by Huq et al. (2017), is strongly indicative of $\mathrm{CO}_{2}$ reduction by the hydrogenotrophic pathway of biogenic methanogenesis (Schoell, 1980). Therefore, the partial oxidation of biogenic methane also provides the simplest explanation for the presence of this gas at high concentrations in pingo outflows further up-valley.

\subsection{Pingos and springs as methane emission hot spots}

The magnitude of annual methane emission from the springs to the atmosphere will very much depend upon the hydrological and meteorological conditions at each pingo site, as well as their variation during the year. During winter, all the sites were characterised by a large ice blister from which periodic outbursts of methane-rich water occurred. During these outbursts, methane emission is most efficient on account of the flow turbulence and likely rejection of methane from the icing formed by the runoff as it gradually freezes (usually within $100 \mathrm{~m}$ of the outburst source). The measurement of the methane evasion from the outburst was impossible under winter conditions, although it was possible to capture the rapid downstream loss of dissolved methane using samples taken opportunistically during an outburst event on 22 April 2015. Figure 5 shows how the downstream methane concentration decreased with distance from the pingo icing 
(a)

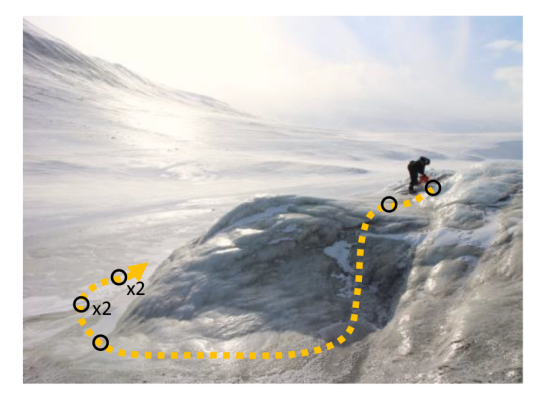

(b)

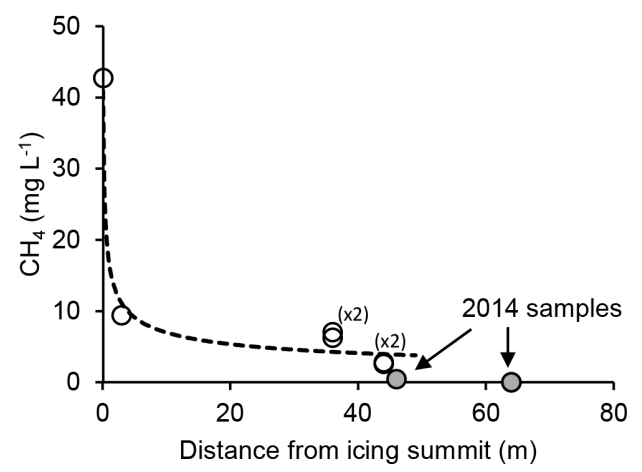

Figure 5. Rapid decrease in dissolved methane concentration with distance from the source of a sub-permafrost groundwater outburst at Innerhytte Pingo summit in April 2015.

summit in a manner described by a regression model of the following form.

$$
\left(\mathrm{CH}_{4(\mathrm{aq})}\right)_{x}=16.9 X^{-0.384}
$$

In this model, $\left(\mathrm{CH}_{4(\mathrm{aq})}\right)_{x}$ is the dissolved methane concentration at distance $X(\mathrm{~m})$ from the pingo icing summit. The coefficient of determination was $0.90(n=6)$ using only the 2015 data. Other samples from the base of the pingo in 2014 are used to show how methane concentrations at greater distances away from the pingo are far lower and thus consistent with further methane loss (see Table 2). The rapid loss of methane was not well accounted for by an exponential model which yielded a coefficient of determination of 0.70 (not shown). Although this outcome is highly sensitive to the single data point at $3 \mathrm{~m}$ from the icing summit, it most likely implies that turbulence was non-linear along the flow path and greatly enhanced the rate of methane evasion as the spring descended the steep, initial part of the pingo flank. Freezing effects were not discernible in the 2015 transect until after the spring flowed onto the flat valley floor (i.e. beyond $50 \mathrm{~m}$ in Fig. 5), where the flow velocities decreased markedly. With this being the case, the data show that $94 \%$ of the methane was most likely lost to the atmosphere within $44 \mathrm{~m}$ of the inferred spring source. During winter, turbulencedriven gas exchange therefore seems most effective near the pingo summit, whilst freezing effects dominate once springs have flowed onto the valley floor (but add little to the overall flux).

During summer, significant changes at the surface of the pingos mean that two key emission scenarios require consideration: (i) a low emission scenario caused by springs discharging straight into a receiving water body, such as a pond (Lagoon Pingo) or the river (Riverbed Pingo), and (ii) a higher emission scenario caused by turbulent discharge down the flank of the pingo (Førstehytte and Innerhytte pingos) and therefore similar to the winter emission scenario but with less freezing effects. Hodson et al. (2019) examined the first scenario at Lagoon Pingo and showed that the pond which forms above the groundwater spring during summer produces an annual emission flux of $42 \mathrm{~kg} \mathrm{CH}_{4} \mathrm{yr}^{-1}$. This is 0.65 times the spring discharge flux of methane brought into the lake according to this work, implying $35 \%$ removal. We presume a similar reduction occurs every summer at Riverbed Pingo site, where a large river engulfs the entire spring, but we lack the observations to assess its effects. However, the pond above Lagoon Pingo does not form every summer due to the susceptibility of the drainage pathway at this site to the disturbance caused by its ice lid collapse. Therefore, in 2020, the system reverted for some weeks into a single spring discharging from a point source, rather like the situation at Innerhytte Pingo. Strong temporal variations in atmospheric methane emissions from pingos are therefore very likely.

The discovery of methane-rich sub-permafrost groundwater discharging from Svalbard's open-system pingos means that other perennial springs also deserve attention because they may be carrying the same fluids. Modelling studies also imply that an increase in the discharge of groundwater systems into surface hydrological networks can be expected as climate change proceeds (Bense et al., 2012). Since these perennial springs result in the formation of winter icings similar to those encountered on the summit or flanks of the pingos, their detection is greatly facilitated. As a consequence, it is well known in Svalbard that they constitute groundwater flows greatly in excess of those observed flowing from pingos (Bukowska-Jania and Szafraniec, 2005), although, like the pingos, the outflows also lack quantitative assessment. Evidence for similar coastal groundwater springs with high methane concentrations that contribute meaningfully to emission fluxes already exist in the MacKenzie Delta, Alaska, where they are thought to contribute approximately $17 \%$ of the emissions from the delta (Kohnert et al., 2017). All forms of sub-permafrost groundwater discharge in Arctic coastal lowlands therefore deserve closer attention in order to better understand changes in the release of sub-permafrost methane to the atmosphere. 


\section{Conclusion}

The development of open-system pingos in Svalbard's coastal lowlands is linked to permafrost aggradation following isostatic uplift. This mechanism results in the expulsion of methane-rich sub-permafrost fluids over the course of centuries at individual sites and establishes pingos as potential hot spots for greenhouse gas emissions. In central Spitsbergen, the concentrations of methane in the springs that discharge from open-system pingos are high (flow-weighted average $17.9 \mathrm{mg} \mathrm{L}^{-1}$; they can even marginally exceed the solubility limit of ca. $41 \mathrm{mg} \mathrm{L}^{-1}$ ). The methane appears to be largely biogenic in origin and subject to moderate levels of oxidation. However, a geogenic methane origin cannot be ruled out because it is present at greater depths beneath the permafrost. The methane is brought to the surface of Adventdalen after groundwater have exploited faults through mudstones of low hydraulic conductivity to the east and sandstones of high hydraulic conductivity to the west. The study of open-system pingos therefore offers rare insights into subpermafrost methane and groundwater dynamics. Since this is one of the least understood potential emission sources, open-system pingos deserve greater research attention so that sub-permafrost emission sources can be integrated with those from the active layer for better emission forecasts.

Data availability. Detailed water quality parameters, including methane concentrations and isotopic composition, for groundwater springs discharging from open-system pingos in Adventdalen, Svalbard (2015-2017), are available at https://doi.org/10.5285/3D82FD3F-884B-47B6-B11C6C96D66B950D (Hodson, 2020).

Author contributions. AJH, AN, PB and MTH collected the samples and analysed the data with significant input from SJ, KR and AVT. The laboratory samples were analysed by SFT, AJH, KR, AM and AVT. AJH wrote the paper with equal editorial input from the remaining authors (KS, HHC and SO).

Competing interests. The authors declare that they have no conflict of interest.

Acknowledgements. The authors acknowledge the Joint Programming Initiative (JPI-Climate Topic 2: Russian Arctic and Boreal Systems) award no. 71126, UK Natural Environment Research Council grant NE/M019829/1, UK Natural Strategic Environment Science Capital Funding, Research Council of Norway grants (NRC nos. 244906 and 294764) and the Royal Geographical Society Ralph Brown Expedition Award 2017. Andrew Fairburn (University of Sheffield) and Stephen Reid (University of Leeds) are thanked for performing the dissolved gas and chemical analysis of the water samples.
Financial support. This research has been supported by the Joint Programming Initiative: Climate (European Union) (grant no. 71126), the Natural Environment Research Council (grant no. NE/M019829/1) and The Research Council of Norway (grant nos. 244906 and 294764).

Review statement. This paper was edited by Peter Morse and reviewed by two anonymous referees.

\section{References}

Anthony, K. M. W., Anthony, P., Grosse, G., and Chanton, J.: Geologic methane seeps along boundaries of Arctic permafrost thaw and melting glaciers, Nat. Geosci., 5, 419-426, 2012.

Bense, V. F., Kooi, H., Ferguson, G., and Read, T.: Permafrost degradation as a control on hydrogeological regime shifts in a warming climate, J. Geophys. Res.-Earth Surf., 117, 1-18, https://doi.org/10.1029/2011JF002143, 2012.

Betlem, P., Senger, K., and Hodson, A.: 3D thermobaric modelling of the gas hydrate stability zone onshore central Spitsbergen, Arctic Norway, Marine and Petroleum Geology, 100, 246-262, 2019.

Bischoff, J. L., Juliá, R., Shanks III, W. C., and Rosenbauer, R. J.: Karstification without carbonic acid: Bedrock dissolution by gypsum-driven dedolomitization, Geology, 22, 95-998, 1994.

Braathen, A., Bælum, K., Christiansen, H. H., Dahl, T., Eiken, O., Elvebakk, H., Hansen, F., Hanssen, T. H., Jochmann, M., Johansen, T. A., Johnsen, H., Larsen, L., Lie, T., Mertes, J., Mørk, A., Mørk, M. B., Nemec, W. J., Olaussen, S., Oye, V., Rød, K., Titlestad, G. O., Tveranger, J., and Vagle, K. Longyearbyen $\mathrm{CO}_{2}$ lab of Svalbard, Norway - first assessment of the sedimentary succession for $\mathrm{CO}_{2}$ storage, Norwegian J. Geol., 92, 353-376, 2012.

Bukowska-Jania, E. and Szafraniec, J.: Distribution and morphometric characteristics of icing fields in Svalbard, Polar Res., 24, 41-53, 2005.

Cable, S., Elberling, B., and Kroon, A.: Holocene permafrost history and cryostratigraphy in the High-Arctic Adventdalen Valley, central Svalbard, Boreas, 47, 423-442, 2018.

Crémière, A., Lepland, A., Chand, S., Sahy, D., Condon, D. J., Noble, S. R., Martma, T., Thorsnes, T., Sauer, S., and Brunstad, H.: Timescales of methane seepage on the Norwegian margin following collapse of the Scandinavian Ice Sheet, Nat. Commun., 7, 11509, https://doi.org/10.1038/ncomms11509, 2016.

Dean, J. F., Middelburg, J. J., Röckmann, T., Aerts, R., Blauw, L. G., Egger, M., Jetten, M. S., de Jong, A. E., Meisel, O. H., Rasigraf, O., and Slomp, C. P.: Methane feedbacks to the global climate system in a warmer world, Rev. Geophys., 56, 207-250, 2018.

Dmitrenko, I. A., Kirillov, S. A., Tremblay, L. B., Kassens, H., Anisimov, O. A., Lavrov, S. A., Razumov, S. O., and Grigoriev, M. N.: Recent changes in shelf hydrography in the Siberian Arctic: Potential for subsea permafrost instability, J. Geophys. Res.Oceans, 116, C10, https://doi.org/10.1029/2011JC007218, 2011.

Dutton, A., Carlson, A. E., Long, A. J., Milne, G. A., Clark, P. U., DeConto, R., Horton, B. P., Rahmstorf, S., and Raymo, M. E.: Sea-level rise due to polar ice-sheet 
mass loss during past warm periods, Science, 349, aaa4019, https://doi.org/10.1126/science.aaa4019, 2015.

Frederick, J. M. and Buffett, B. A.: Submarine groundwater discharge as a possible formation mechanism for permafrostassociated gas hydrate on the circum-Arctic continental shelf, J. Geophys. Res.-Earth, 121, 1383-1404, 2016.

Gautier, D. L., Bird, K. J., Charpentier, R. R., Grantz, A., Houseknecht, D. W., Klett, T. R., Moore, T. E., Pitman, J. K., Schenk, C. J., Schuenemeyer, J. H., and Sørensen, K.: Assessment of undiscovered oil and gas in the Arctic, Science, 324, 1175-1179, 2009.

Gilbert, G. L., Cable, S., Thiel, C., Christiansen, H. H., and Elberling, B.: Cryostratigraphy, sedimentology, and the late Quaternary evolution of the Zackenberg River delta, northeast Greenland, The Cryosphere, 11, 1265-1282, https://doi.org/10.5194/tc-11-1265-2017, 2017.

Gilbert, G. L., O’Neill, H. B., Nemec, W., Thiel, C., Christiansen, H. H., and Buylaert, J. P.: Late Quaternary sedimentation and permafrost development in a Svalbard fjord-valley, Norwegian high Arctic, Sedimentology, 65, 2531-2558, 2018.

Hindshaw, R. S., Lang, S. Q., Bernasconi, S. M., Heaton, T. H. E., Lindsay, M. R., and Boyd, E. S.: Origin and temporal variability of unusually low $\delta^{13} \mathrm{C}$-DOC values in two High Arctic catchments, J. Geophys. Res.-Biogeo., 121, 1073-1085, 2016.

Hodson, A.: Detailed water quality parameters, including methane concentrations and isotopic composition, for groundwater springs discharging from open system pingos in Adventdalen, Svalbard (2014-2017), Polar Data Centre, Natural Environment Research Council, UK Research \& Innovation, https://doi.org/10.5285/3d82fd3f-884b-47b6-b11c6c96d66b950d, 2020.

Hodson, A., Nowak, A., and Christiansen, H. H.: Glacial and periglacial floodplain sediments regulate hydrologic transfer of reactive iron to a high arctic fjord, Hydrol. Process., 30, 1219 1229, 2016.

Hodson, A. J., Nowak, A., Holmlund, E., Redeker, K. R., Turchyn, A. V., and Christiansen, H. H.: Seasonal dynamics of Methane and Carbon Dioxide evasion from an open system pingo: Lagoon Pingo, Svalbard, Front. Earth Sci., 7, 30, https://doi.org/10.3389/feart.2019.00030, 2019.

Hornum, M. T., Hodson, A. J., Jessen, S., Bense, V., and Senger, K.: Numerical modelling of permafrost spring discharge and opensystem pingo formation induced by basal permafrost aggradation, The Cryosphere Discuss., https://doi.org/10.5194/tc-20207, in review, 2020.

Huq, F., Smalley, P. C., Mørkved, P. T., Johansen, I., Yarushina, V., and Johansen, H.: The Longyearbyen $\mathrm{CO}_{2}$ Lab: Fluid communication in reservoir and caprock, Int. J. Greenhouse Gas Control, 63, 59-76, 2017.

Keating, K., Binley, A., Bense, V., Van Dam, R. L., and Christiansen, H. H.: Combined geophysical measurements provide evidence for unfrozen water in permafrost in the Adventdalen valley in Svalbard, Geophys. Res. Lett., 45, 7606-7614, 2018.

Kohnert, K., Serafimovich, A., Metzger, S., Hartmann, J., and Sachs, T.: Strong geologic methane emissions from discontinuous terrestrial permafrost in the Mackenzie Delta, Canada, Sci. Rep.-UK, 7, 5828, https://doi.org/10.1038/s41598-017-05783-2, 2017.
Lacelle, D.: On the $\delta^{18} \mathrm{O}, \delta \mathrm{D}$ and $\mathrm{D}$-excess relations in meteoric precipitation and during equilibrium freezing: theoretical approach and field examples, Permafrost Periglac., 22, 13-25, 2011.

Liestøl, O.: Open System pingos in Spitsbergen, Norsk Geogr. Tidsskr., 50, 81-84, 1996.

Liira, M., Noormets, R., Sepp, H., Kekišev, O., Maddison, M., and Olaussen, S.: Sediment geochemical study of hydrocarbon seeps in Isfjorden and Mohnbukta: a comparison between western and eastern Spitsbergen, Svalbard, Arktos, 5, 49-62, 2019.

Magen, C., Lapham, L. L., Pohlman, J. W., Marshall, K., Bosman, S., Casso, M., and Chanton, J. P.: A simple headspace equilibration method for measuring dissolved methane, Limnol. Oceanogr. Methods, 12, 637-650, 2014.

Mau, S., Römer, M., Torres, M. E., Bussmann, I., Pape, T., Damm, E., Geprägs, P., Wintersteller, P., Hsu, C. W., Loher, M., and Bohrmann, G.: Widespread methane seepage along the continental margin off Svalbard-from Bjørnøya to Kongsfjorden, Sci. Rep.-UK, 7, 42997, https://doi.org/10.1038/srep42997, 2017.

McAuliffe, C.: Gas Chromatographic determination of solutes by multiple phase equilibrium, Chem. Technol., 1, 46-51, 1971.

Ohm, S. E., Larsen, L., Olaussen, S., Senger, K., Birchall, T., Demchuk, T., Hodson, A., Johansen, I., Titlestad, G. O., Karlsen, D. A., and Braathen, A.: Discovery of shale gas in organic rich Jurassic successions, Adventdalen, Central Spitsbergen, Norway, Norwegian J. Geol., 99, 349-276, 2019.

Olaussen, S., Senger, K., Braathen, A., Grundvåg, S. A., and Mørk, A.: You learn as long as you drill; research synthesis from the Longyearbyen $\mathrm{CO}_{2}$ Laboratory, Svalbard, Norway, Norwegian J. Geol., 99, 157-181, 2019.

Pohlman, J. W., Greinert, J., Ruppel, C., Silyakova, A., Vielstädte, L., Casso, M., Mienert, J., and Bünz, S.: Enhanced $\mathrm{CO}_{2}$ uptake at a shallow Arctic Ocean seep field overwhelms the positive warming potential of emitted methane, P. Natl. Acad. Sci. USA, 114, 5355-5360, 2017.

Portnov, A., Vadakkepuliyambatta, S., Mienert, J., and Hubbard, A.: Ice-sheet-driven methane storage and release in the Arctic, Nat. Commun., 7, 10314, https://doi.org/10.1038/ncomms10314, 2016.

Rozanski, K., Araguás-Araguás, L., and Gonfiantini, R.: Isotopic patterns in modern global precipitation, in: Climate change in Continental Isotopic Records, edited by: Swart, P. K., Lohmann, K. C., McKenzie, J., and Savin, S., Geophysical Monograph No. 78, American Geophysical Union, Washington D.C., 1-36, 1993.

Rutter, N., Hodson, A., Irvine-Fynn, T., and Solås, M. K.: Hydrology and hydrochemistry of a deglaciating high-Arctic catchment, Svalbard, J. Hydrol., 410, 39-50, 2011.

Sahling, H., Römer, M., Pape, T., Bergès, B., dos Santos Fereirra, C., Boelmann, J., Geprägs, P., Tomczyk, M., Nowald, N., Dimmler, W., Schroedter, L., Glockzin, M., and Bohrmann, G.: Gas emissions at the continental margin west of Svalbard: mapping, sampling, and quantification, Biogeosciences, 11, 6029-6046, https://doi.org/10.5194/bg-11-6029-2014, 2014.

Schoell, M.: The hydrogen and carbon isotopic composition of methane from natural gases of various origins, Geochim. Cosmochim. Ac., 44, 649-661, 1980.

Smith, L. M., Sachs, J. P., Jennings, A. E., Anderson, D. M., and DeVernal, A.: Light $\delta^{13} \mathrm{C}$ events during deglaciation of the East 
Greenland continental shelf attributed to methane release from gas hydrates, Geophys. Res. Lett., 28, 2217-2220, 2001.

Smith, R. W., Bianchi, T. S., Allison, M., Savage, C., and Galy, V.: High rates of organic carbon burial in fjord sediments globally, Nat. Geosci., 8, 450-453, 2015.

Syvitski, J. P. M., Burrell, D. C., and Skei, J. M.: Fjords: Processes and Products, Springer, New York, 377 pp., 1986.

Tyler, S. C., Bilek, R. S., Sass, R. L., and Fisher, F. M.: Methane oxidation and pathways of production in a Texas paddy field deduced from measurements of flux, $\delta^{13} \mathrm{C}$, and $\delta \mathrm{D}$ of $\mathrm{CH}_{4}$, Global Biogeochem. Cycles, 11 323-348, 1997.

Weitemeyer, K. A. and Buffett, B. A.: Accumulation and release of methane from clathrates below the Laurentide and Cordilleran ice sheets, Global Planet. Change, 53, 176-187, 2006.
Włodarska-Kowalczuk, M., Mazurkiewicz, M., Górska, B., Michel, L. N., Jankowska, E., and Zaborska, A.: Organic carbon origin, benthic faunal consumption and burial in sediments of northern Atlantic and Arctic fjords (60-81 $\left.{ }^{\circ} \mathrm{N}\right)$, J. Geophys. Res.-Biogeo., 124, 3737-3751, 2019.

Yde, J. C., Riger-Kusk, M., Christiansen, H. H., Knudsen, N. T., and Humlum, O.: Hydrochemical characteristics of bulk meltwater from an entire ablation season, Longyearbreen, Svalbard, J. Glaciol., 54, 259-272, 2008.

Yoshikawa, K.: Notes on open-system pingo ice, Adventdalen, Spitsbergen, Permafrost Periglac., 4, 327-334, 1993.

Yoshikawa, K. and Nakamura, T.: Pingos growth age in the delta area, Adventdalen Spitsbergen, Polar Rec., 32, 347-352, 1996. 